\title{
Climate risk and agricultural technology adaption: evidence from rice farmers in the Ayeyarwady River delta of Myanmar
}

\author{
Rie Muraoka ${ }^{1,3}$ (D) Jun Furuya ${ }^{1}$ (D) $\cdot$ Akira Hirano $^{1}$ (D) Takeshi Sakurai $^{2}$
}

Received: 11 February 2021 / Revised: 22 August 2021 / Accepted: 24 August 2021 / Published online: 27 September 2021

(c) The Author(s) 2021

\begin{abstract}
Crop income can be raised in two ways: one way is to increase crop productivity and the other is to grow high-value crops that could be sold at high prices in the market. This study evaluated the adoption determinants of high-yielding varieties (HYVs) and high-value varieties (HVVs) of rice and their associations on crop income using data collected in coastal areas of the Ayeyarwady River delta, which is prone to climate shocks such as saltwater intrusion and cyclones. We used crosssectional data on 298 rice-producing households and 393 rice plots to conduct multinomial logit estimates, which revealed that the heights of the plots, and past exposure to saltwater intrusion negatively affected the adoption of HVVs. Our estimates also suggest that while the adoption of HYVs is not associated with high rice yield, income, or profit, HVV adoption is associated with high income and profit.
\end{abstract}

Keywords Technology adoption $\cdot$ Myanmar $\cdot$ Rice $\cdot$ Improved rice varieties $\cdot$ Climate shocks

\section{Introduction}

Poverty alleviation is one of the major goals of international development and foremost among the Sustainable Development Goals (United Nations 2021). Although Myanmar has been experiencing rapid economic growth since the country's “opening up" in 2011, it continues to report a high poverty rate, at $24.8 \%$ in 2017 (Asian Development Bank 2021). The poverty headcount is 2.7 times higher in rural areas $(30.2 \%)$ than in urban areas (11.3\%) (World Bank 2019). Given that $70 \%$ of Myanmar's population lives in rural areas and most of them engage in agriculture, increasing rural farmers' income is imperative for eradicating rural poverty in Myanmar (International Rice Research Institute 2020; United Nations Office for Project Services 2021).

Rie Muraoka

muraokarie@affrc.go.jp

1 Social Science Division, Japan International Research Center for Agricultural Sciences, 1-1 Ohwashi, Tsukuba, Ibaraki 305-8686, Japan

2 Graduate School of Agricultural and Life Sciences, The University of Tokyo, 1-1-4 Yayoi, Bunkyo-ku, Tokyo 113-8657, Japan

3 National Graduate Institute for Policy Studies, Tokyo, Japan
There are two main ways to increase crop income. The first way is to improve land productivity, through means like the adoption of HYVs. Studies have shown that the adoption of improved varieties significantly increases yield (Villano et al. 2015; Zeng et al. 2015), and crop and household income (Bezu et al. 2014; Kassie et al. 2011; Khonje et al. 2015; Manda et al. 2019; Mathenge et al. 2014; Smale and Mason 2014; Verkaart et al. 2017; Villano et al. 2015). The second way is to cultivate high-value crops. With the growth of demand for high-quality food in developing countries (Banerjee et al. 2011), poor farmers are also exhibiting a preference for quality over quantity (Deaton and Drèze 2009; Jensen and Miller 2008). Farmers producing highvalue crops could earn high net incomes. A growing body of literature has shown that the adoption of commercial crops, such as fruits, vegetables, and tobacco, has positive effects on household income and welfare (Briones 2015; Rao and Qaim 2011; Miyata et al. 2009; Narayanan 2014; Amare et al. 2019). Regarding staple crops, Minten et al. (2013) reported that the price premium of fine rice in Bangladesh mostly benefits the off-farm food sectors, such as millers and retailers; not much is received by the farmers.

Most studies have tended to focus on the adoption and effects of either HYVs or HVVs on incomes, but not both. Among the varieties available, farmers face multiple choices including local, high-yielding, or high-value varieties, and 
the determinants of these choices need to be analyzed. To the best of our knowledge, no study has examined the determinants of choice among the available varieties: local varieties (LVs), HYVs, and HVVs. Therefore, our study attempted to fill this gap in two ways. First, we examined the factors affecting multiple rice variety choices by utilizing crosssectional data collected in 2017 from the Ayeyarwady delta in Myanmar. Given the multiple choices, we employed multinomial logit regressions. Second, we attempted to quantify the association of both HYVs and HVVs on rice yield, income, and profit. We adopt Oster's methodology (2019) for evaluating robustness to omitted variable bias.

\section{Rice varieties in Myanmar}

Rice is the predominant cereal crop grown in Myanmar. As of 2019 , rice production is estimated at about $90 \%$ of the total cereal production in Myanmar (Food and Agriculture Organization 2021). Rice is grown on 7.3 million hectares, or $60 \%$ of the country's total cultivated area (Ministry of Agriculture, Livestock, and Irrigation 2019). Additionally, rice production employs $70 \%$ of the rural labor force (Ministry of Agriculture and Irrigation 2015). Therefore, yield and income enhancement of rice production are among the key factors of rural development, food security, and poverty reduction in Myanmar.

Although rice is the main agricultural crop in Myanmar, the country's rice yield is not as high as other Southeast Asian countries. In 2019, Myanmar's paddy yield was approximately 3.8 metric tons (MT) per hectare, whereas Vietnam and Indonesia's yields were estimated at 5.8 MT and 5.1 MT per hectare, respectively (FAOSTAT 2021). To achieve sustainable development of the rice sector, the Ministry of Agriculture and Irrigation (MoAI) ${ }^{1}$ in Myanmar formulated a Myanmar Rice Sector Development Strategy (MRSDS) in 2015. MRSDS aims to make Myanmar a major contributor to regional and global food security by 2030 , through the sustainable intensification of rice production. The sustainable increase in rice productivity is one of the 10 key themes of MRSDS. To achieve this goal, MRSDS stresses the importance of breeding and promoting higheryielding and stress-tolerant varieties appropriate to farmer and market preferences (MoAI 2015).

Among HYVs, IR8, which was bred by the International Rice Research Institute (IRRI), was first introduced in Myanmar in the 1960s (Win 1991). Since then, the Department of Agriculture (DoA) of Myanmar and IRRI have developed many improved rice varieties and attempted to diffuse them

\footnotetext{
${ }^{1}$ Currently, it is called the Ministry of Agriculture, Livestock, and Irrigation (MoAI).
}

Table 1 Rice varieties planted and their sales prices

\begin{tabular}{lrl}
\hline Name of rice variety & No. of plots & $\begin{array}{l}\text { Sales price } \\
(\mathrm{MMK} / \mathrm{kg})\end{array}$ \\
\hline HYVs & 22 & 5264 \\
Ma Naw Thukha & 6 & 5660 \\
Ma Naw Ha Ri & 6 & 5000 \\
Other & 34 & 5276 \\
Total & & \\
HVVs & 192 & 7242 \\
Paw San & 21 & 6971 \\
Paw San Yin & 213 & 7216 \\
Total & & \\
LVs & 97 & 5725 \\
Kyauk Kyi & 39 & 4805 \\
Nga Sein & 11 & 5733 \\
Other & 147 & 5549 \\
Total &
\end{tabular}

$M M K$ Myanmar Kyat

among rice farmers in Myanmar (IRRI 2020). For example, IRRI released 74 new rice varieties by 2020 (IRRI 2020). These improved rice varieties are being used by $40-50 \%$ of the small-scale rice farmers in Myanmar (IRRI 2020).

The Ayeyarwady River delta is the largest "rice bowl" in Myanmar, with an area of $35,032 \mathrm{~km}^{2}$ (MoAI 2015). It has fertile soil and abundant rainfall that provide suitable conditions for rice farming. This region, however, is rather vulnerable to climate shocks, such as cyclones, floods, saltwater intrusion, and droughts (MoAI 2015; Thant et al. 2020). For example, Cyclone Nargis hit the Ayeyarwady River delta in 2008 , killing 138,373 people and bringing catastrophic damage to the region (Swiss Reinsurance Company Ltd. 2009). HYVs are planted in only $59 \%$ of the rice fields in the lower Ayeyarwady delta region, compared with $98 \%$ in the upper regions (Thant et al. 2020) and reflect the severe environmental conditions in the lower region. Thus, farmers prefer LVs that have adjusted and adapted to the harsh local environments over time. In this study, we conducted a survey in the coastal areas of the lower Ayeyarwady River delta region, where flooding and saltwater intrusion are more severe compared with the other regions of the delta. Table 1 shows that HYVs are planted in only $8.7 \%$ of all plots in the survey area. The HYVs (e.g., Ma Naw Thukha and Ma Naw Ha Ri) adopted by farmers in the survey area are not salinityand flood-tolerant and are normally grown in upland areas. Therefore, whether HYVs would raise land productivity is an empirical question that we seek to answer, given the climatically harsh environment in the low-lying, coastal areas of the Ayeyarwady River delta.

Improving rice yield is one way to increase rice farmers' income. Another way is growing HVVs that could be sold 
at high prices and can be expected to bring high income. Paw San series rice is a very popular local high-quality rice variety, valued for its taste, fluffiness, texture, and aroma (Myint and Napasintuwong 2016). Paw San series rice was declared the world's best rice at the World Rice Conference in 2011. As shown in Table 1, the farm gate price of Paw San series rice is about 1.3-1.4 times higher than LV and HYV average prices. However, the land productivity of the Paw San series rice is not as high as that of HYVs. Paw San series rice can be grown in flooded areas, but only with good water drainage. Paw San series rice is also difficult to grow in lowland areas without embankments because the water level is likely to remain stable even when the rains stop. Our study also aims to elucidate the empirical question of whether planting HVVs, such as Paw San series rice, can lead to high incomes, given its low yield, and the harsh environmental conditions in the low-lying, coastal areas of the Ayeyarwady River delta. By utilizing data collected in the low areas of the Ayeyarwady River delta, we attempt to quantify the determinants of HYV and HVV (Paw San series rice) adoption and examine their effects on rice yield, income, and profit, in comparison with LVs.

\section{Estimation strategies}

\section{Adoption determinants}

We modeled the adoption decision regarding rice varieties in a random utility model following Ali and Abdulai (2010), Becerril and Abdulai (2010), and Crost et al. (2007). We categorized the rice variety choices into three categories: HYVs, HVVs, and LVs. These unordered multinomial outcomes were based on each farmer's choice. $U_{i j k}$ is the utility of adopting rice variety $k$ by individual $i$ on rice plot $j$. Following Cameron and Trivedi (2010), we set $U_{i j k}$ to be the sum of a deterministic component $V_{i j k}$ and an unobserved random component $\varepsilon_{i j k}$.

$U_{i j k}=V_{i j k}+\varepsilon_{i j k}$

where $i=1, \ldots, I, j=1, \ldots, J$, and $k=1, \ldots, K$. Model (1) is called a random utility model. $V_{i j k}$ could be expressed as follows.

$V_{i j k}=x_{i k}^{\prime} \beta+z_{i j k}^{\prime} \gamma$

$x_{i}$ is the vector of household-level case-specific regressors that explain farmers' adoption decisions regarding the rice

\footnotetext{
${ }^{2}$ Paw San series rice includes Paw San, Paw San Gyi, Paw San Lat, and Paw San Yin. Their differences are based on the length of the growing period.
}

variety to plant, including: sex, age, and years of schooling of the household head; household size; value of total assets; experience (number) of cyclones, drought, saltwater intrusion, and other disasters that affected crop production in the past nine years; and degree of risk tolerance. $z_{i j}$ is the vector of plot-level case-specific variables, such as plot size, distance to river, distant to home, height of plot, access to irrigation, drainage, and public and private dikes.

The rice variety choice outcome $d_{k}$ would be realized if alternative $k$ has the highest utility among other alternatives, including alternative $l$. Cameron and Trivedi (2010) expressed this choice as follows.

$$
\begin{aligned}
\operatorname{Pr}\left(d_{i j}=k\right) & =\operatorname{Pr}\left(U_{i j k} \geq U_{i j l}\right), \quad \text { for all } l \\
& =\operatorname{Pr}\left(U_{i j l}-U_{i j k} \leq 0\right) \\
& =\operatorname{Pr}\left(\varepsilon_{i j l}-\varepsilon_{i j k} \leq V_{i j k}-V_{i j l}\right) \\
& =\operatorname{Pr}\left\{\varepsilon_{i j l}-\varepsilon_{i j k} \leq\left(x_{i k}-x_{i l}\right)^{\prime} \beta+\left(z_{i j k}-z_{i j l}\right)^{\prime} \gamma\right\}
\end{aligned}
$$

We adopted a multinomial response model that accounted for several options to estimate model (2). We relied on the multinomial logit (MNL) model despite its very restrictive assumption of independence from irrelevant alternatives (IIA). This assumption states that adding another alternative or changing the characteristics of a third alternative does not change the relative odds between other alternatives (Wooldridge 2010). The multinomial probit (MP) model is an option because it does not require the IIA assumption. However, Cameron and Trivedi (2010) argued that the MP model is not ideal because its computation is often made infeasible by a computational burden, ${ }^{3}$ and the estimation results of the MNL and MP models are anyway quantitatively similar. ${ }^{4}$

Model (2) could be rewritten as follows (Cameron and Trivedi, 2010):

$p_{i j k}=\frac{\exp \left(x_{i}^{\prime} \beta_{k}+z_{i j}^{\prime} \gamma_{k}\right)}{\sum_{l=1}^{K} \exp \left(x_{i}^{\prime} \beta_{l}+z_{i j}^{\prime} \gamma_{l}\right)}$,

where $p_{i j}$ is the probability of farm household $i$ choosing rice variety $k$ on plot $j$. This model ensures that $0<p_{i j k}<1$ and $\sum_{k=1}^{K} p_{i j k}=1$.

Farmers' experience of climate shocks that affected their crop production in nine years represented one of the key variables in our estimation. As explained in the "Rice varieties

\footnotetext{
${ }^{3}$ Given $J$ options, the multinomial probit involves $(J+1)$ dimensional integration, which has no closed-form solution and is difficult to compute (Cameron and Trivedi 2010; Wooldridge 2010).

4 The IIA test results showed that the IIA assumption was not violated in our estimation.
} 
in Myanmar" section, the Ayeyarwady River delta is known to be prone to climate shocks, such as flooding, saltwater intrusion, and drought. Studies have shown that exposure to weather shocks affects current agricultural technology adoption decisions (refer to Alem et al. (2010) and Arslan et al. (2017) for evidence on Ethiopia and Tanzania, respectively). Using data from Ethiopia, Cavatassi et al. (2011) demonstrated that farmers who had been exposed to moderate climate shocks tended to adopt early maturing, improved sorghum varieties, whereas those who had experienced extreme weather events preferred to adopt landraces. Farmers regard landraces as more suitable for coping with severe downside risk compared with modern improved varieties. Given that the HYVs and HVVs adopted in the survey areas are not stress-tolerant varieties, we hypothesize that exposure to weather shock would negatively affect rice farmers' decisions to adopt HYVs and HVVs.

Another key variable is the degree of risk tolerance, which could affect the technology adoption decisions and behavior of rural farmers. Given the high climate risk in the Ayeyarwady River delta, risk-averse farmers could be more reluctant to adopt HYVs and/or HVVs. Holden and Quiggin (2017) showed that in the drought-prone areas of Malawi, more risk-averse households are more likely to droughttolerant varieties, less likely to adopt other improved maize varieties, and less likely to have dis-adopted traditional local maize. In the survey, we measured the degree of risk tolerance of rice farmers. ${ }^{5}$ Using this variable, we attempt to examine the relation between risk preference and the adoption decisions of farmers regarding rice varieties. Additionally, the inclusion of the degree of risk tolerance is expected to control for unobserved characteristics that may affect farmers' rice adoption choices.

\section{Association between the adoption of HYVs and HVVs, rice yield and income}

Next, we sought to decipher the associations of adoption. We first hypothesize that HYVs would realize the highest rice yield, given their high-yielding traits. Second, we postulate that the adoption of HYVs and HVVs would yield higher rice income compared with LVs. To test these hypotheses, we specify the production function model as follows:

$y_{i j}=\beta d_{i j}+x_{i}^{\prime} \gamma+z_{i j}^{\prime} \theta+\varepsilon_{i j}$

\footnotetext{
5 See "Appendix" for the details on how we measured risk tolerance.
}

where $y_{i j}$ is either the log of rice yield (log of amount of rice harvested per acre) ${ }^{6}$ rice income (value of rice harvested minus cost of rice cultivation per acre), or rice profit (value of rice harvested minus all the costs evaluated at shadow prices per acre) of plot $j$ belonging to household $i . d_{i j}$ is a dummy variable for plot-level rice variety choice that is equal to 1 for HYVs (or for HVVs) and 0 for plots with other LVs.

The ordinary least squares (OLS) estimation of $\beta$ is likely to be biased because unobservable variables such as innate farmers' ability, farmers' social networking, unmeasured wealth, and the soil quality of each plot could affect both rice variety choices and the outcome variables. To address this issue, we adopt the methodology developed by Oster (2019) for evaluating robustness and omitted variable bias; Oster's (2019) methodology is an extension of the work of Altonji et al. (2005). This requires the assumption of proportional selection, which is the relationship between the treatment and unobserved variables that can be recovered, from the relationship between treatment and unobserved variables (Khan et al. 2019; Oster 2019).

Oster (2019) suggested two approaches to test robustness. One is to calculate $\delta$, the coefficient of proportionality between observables and unobservables, to drive our estimated coefficients of treatment to zero. This can also be interpreted as the degree of selection on unobservables relative to observables that would be necessary to explain the result (Oster 2019). $\delta$ is defined as follows (Khan et al. 2019):

$\delta \approx \frac{\left(\tilde{\beta}-\beta^{*}\right)\left(\tilde{R}-R^{\circ}\right)}{\left(\beta^{\circ}-\tilde{\beta}\right)\left(R_{\max }-\tilde{R}\right)}$

where $\beta^{\circ}$ is the coefficient from the short regression of the outcome variable on treatment, and $R^{\circ}$ is the R-squared from that regression; $\tilde{\beta}$ is the coefficient from the regression of the outcome variable on treatment and all observed explanatory variables; $\tilde{R}$ is the $\mathrm{R}$-squared from that regression; $\beta^{*}$ is the targeted value of the coefficient (that is zero in our case); and $R_{\max }$ is the R-squared from a hypothetical regression of the outcome variable on treatment, all observed, and unobserved variables. Oster (2019) suggested $R_{\max }=1.3 \tilde{R}$, and $\delta=1$ as an appropriate cutoff. $\delta=1$ indicates that the observables are at least important as the unobservables.

The other approach to the robustness test is to estimate a set of bounds for $\beta$ (Oster 2019). One bound is $\tilde{\beta}$ which is the value of $\beta$ when $\delta=0$, while the other bound is $\beta^{*}$ which

\footnotetext{
$\overline{6}$ To reflect the Cobb-Douglas production function, we take the natural log of the rice yield but not of the rice income and profit, because quite a few observations have negative indicators of rice income and profit.
} 
Fig. 1 Location of the surveyed village tracts in Labutta Township

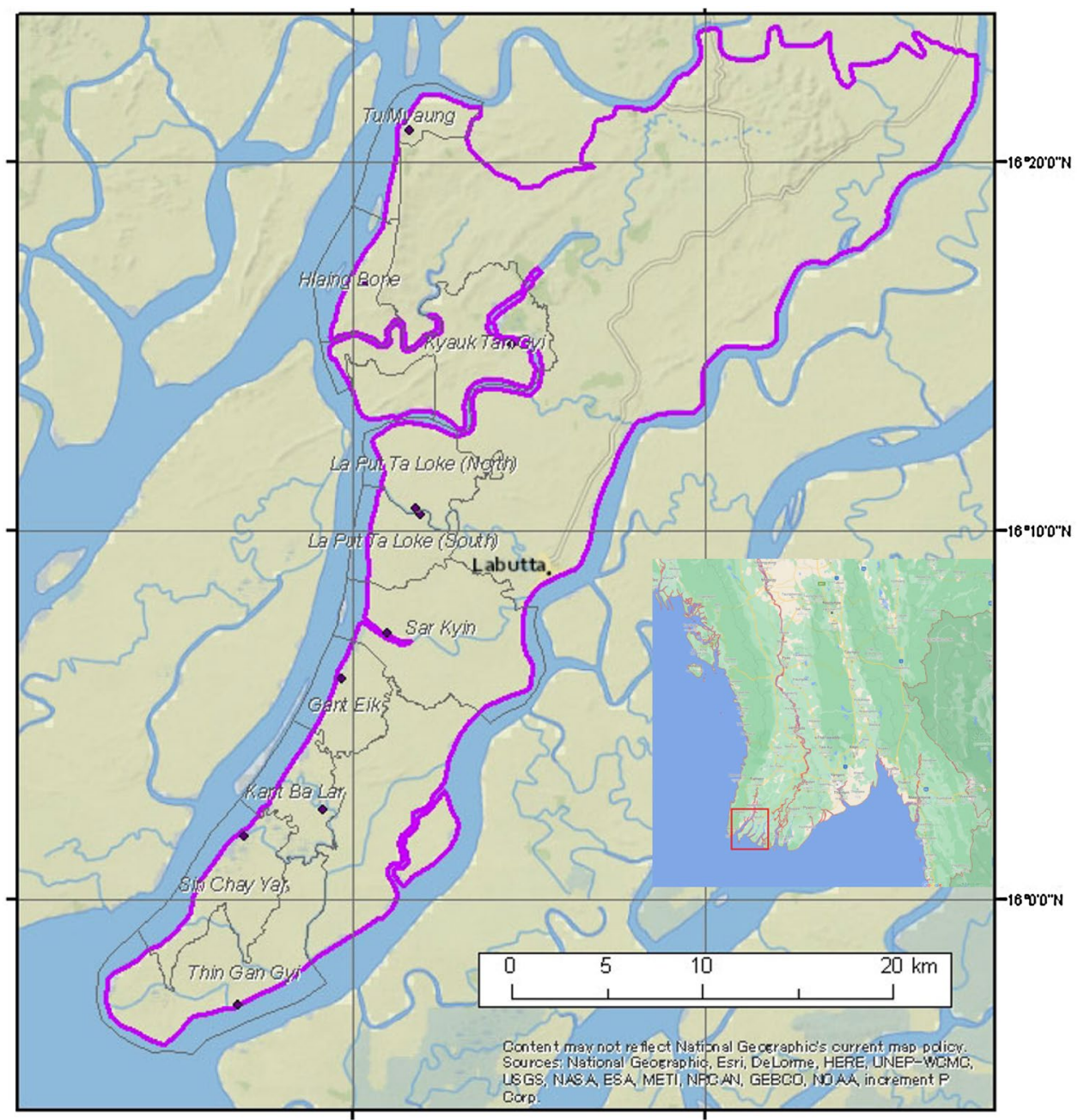

is the value of $\beta$ when $\delta=1$ and $R^{2}=R_{\max }$. If these sets of bounds do not include zero, we conclude that our controlled coefficient is robust (Oster 2019).

We adopt both approaches in our study to test the robustness of our estimates. Though this test is developed to explore causality, we interpret our results as deriving from association rather than causal impacts, because we cannot test the assumption of proportional selection.

\section{Data and descriptive statistics}

\section{Data}

This study relied on data collected in the Labutta Township of the Ayeyarwady Region in 2017. Labutta Township is one of the two townships in the Labutta District, which is located along the banks of the Yway River. Labutta Township was severely hit by Cyclone Nargis in 2008, resulting in extensive damage. Thus, we expected the population in Labutta Township to be aware of the risks of natural disasters. The interview survey was conducted jointly by the Japan International Research Center for Agricultural Sciences and Yezin Agricultural University. The survey team selected 10 village tracts along the river mouth and randomly selected approximately 30 households in each village tract from the official list of land-owning rice farmers. The location of the surveyed village tracts is shown in Fig. 1. We conducted face-to-face interviews on rice production with the head of each household or another household member, if the head was absent, during February and March $2017 .{ }^{7}$ We inquired about the details of rice production in the cropping season of 2016. In total, we collected data from 304 households and 562 rice plots. The survey data included detailed household and plot information on rice production, input use, yield, plot characteristics, demographics, education, and assets. As discussed in Carletto et al. (2013), self-reported land size often involves land measurement errors. Thus, we referred

\footnotetext{
7 We conducted interviews for households who submitted their written informed consent only.
} 
Table 2 Sample household characteristics

\begin{tabular}{|c|c|c|c|c|c|c|c|c|}
\hline & \multicolumn{2}{|l|}{ Total } & \multicolumn{2}{|c|}{ Adopters of HYVs } & \multicolumn{2}{|c|}{ Adopters of HVVs } & \multicolumn{2}{|c|}{ Adopters of only LVs } \\
\hline & Mean & SD & Mean & SD & Mean & SD & Mean & SD \\
\hline Number of households & 298 & & 33 & & 212 & & 65 & \\
\hline Women-headed household $(=1)$ & 0.11 & $(0.31)$ & 0.12 & $(0.33)$ & 0.11 & $(0.32)$ & 0.09 & $(0.29)$ \\
\hline Age of the household head (years) & 52 & $(13.0)$ & 52 & $(12.8)$ & 52 & $(12.6)$ & 52 & $(14.5)$ \\
\hline Schooling years of the household head & 6.2 & $(2.9)$ & 5.9 & $(3.0)$ & 6.2 & $(2.9)$ & 6.0 & $(2.9)$ \\
\hline Household size & 4.2 & $(1.8)$ & $4.8^{*}$ & $(2.1)$ & 4.2 & $(1.8)$ & 4.1 & $(1.7)$ \\
\hline $\begin{array}{l}\text { Number of working adults (15-64 years } \\
\text { old) }\end{array}$ & 2.9 & (1.3) & 3.1 & (1.3) & 2.9 & $(1.4)$ & 2.8 & $(1.1)$ \\
\hline Value of non-land assets (MMK) & $4,581,330$ & $(6,102,034)$ & $4,367,924$ & $(3,109,478)$ & $4,791,125$ & $(6,894,754)$ & $3,990,262$ & $(3,424,265)$ \\
\hline $\begin{array}{l}\text { Experience of saltwater intrusion in the } \\
\text { past nine years (frequency) }\end{array}$ & 0.36 & $(0.48)$ & $0.21 * * *$ & $(0.42)$ & $0.33 * *$ & $(0.47)$ & 0.51 & $(0.50)$ \\
\hline $\begin{array}{l}\text { Experience of cyclone in the past nine } \\
\text { years (frequency) }\end{array}$ & 0.44 & $(0.50)$ & 0.36 & $(0.49)$ & 0.43 & $(0.50)$ & 0.46 & $(0.50)$ \\
\hline $\begin{array}{l}\text { Experience of drought in the past nine } \\
\text { years (frequency) }\end{array}$ & 0.48 & $(1.29)$ & 0.55 & $(1.30)$ & 0.51 & $(1.38)$ & 0.34 & $(0.89)$ \\
\hline $\begin{array}{l}\text { Experience of other climate shocks in the } \\
\text { past nine years (frequency) }\end{array}$ & 1.73 & $(2.52)$ & 1.85 & $(2.27)$ & 1.82 & $(2.67)$ & 1.40 & $(2.06)$ \\
\hline Degree of risk tolerance (from 2 to 9 ) & 2.13 & $(2.55)$ & 2.48 & $(2.85)$ & $2.28 *$ & $(2.71)$ & 1.71 & (1.97) \\
\hline
\end{tabular}

$* * *$ and $* *$ indicate significance at $1 \%$ and $5 \%$, respectively

We conducted significance testing of the differences in means between adopters of HYVs and those of only LVs, and adopters of HVVs and those of only LVs

to each plot size as listed in the official land registers. As we chose the sample households randomly from selected village tracts and since the outcome indicators in a village tract may correlate, we clustered standard errors by village tract in the estimation models (3) and (4).

To grasp locational relations between the farm plots, we recorded the distance from the nearest river or coast, to the homesteads of the locations of the 423 farm plots owned by 304 households, using high-resolution Google Earth images through the interview survey. Rivers were manually digitized from United States Geological Survey Landsat-8 image data that were orthorectified and pan-sharpened at a spatial resolution of $15 \mathrm{~m}$. We computed the distances from each farm plot to the nearest riverbank or coastal line using a GIS function that could find the shortest path between a point and a linear feature. The open-source QGIS was used to facilitate the GIS operation.

After merging household- and plot-level data from the interviews and GIS data, and cleaning the data, our observations reduced from 562 plots owned by 304 households to 393 plots owned by 298 households. The attrition rate of observations because of missing data was $30 \%$, which is a large reduction. Thus, we conducted an attrition test and found that the attrition occurred nonrandomly. Hence, inverse probability weights were estimated based on the methods of Fitzgerald et al. (1998) and Wooldridge (2010) and used to control for potential attrition bias in all the regressions in this study. To eliminate outlier issues in explanatory and outcome variables, we winsorized all the values at the 99th percentile.

\section{Descriptive statistics}

We divided the sample households into three non-mutually exclusive categories: households that adopted HYVs on at least one plot, those that adopted HVVs on at least one plot, and those that adopted only LVs. Their characteristics are given in Table 2. The adoption of HYVs is not common in the survey area; only $11 \%$ of the households adopted HYVs on at least one of their rice plots. In contrast, the adoption of HVVs is common; more than $71 \%$ of the households adopt HVVs on at least one of their plots. About $22 \%$ of the households adopt only LVs on all their plots.

As shown in Table 2, the percentage of women-headed households is about $11 \%$, the average age of household heads is 52 years, and the average number of years of schooling of the household heads was 6.2 years. Adopters of HYVs tend to have larger-sized households than those of LVs, although the difference in the number of working-age adults, defined as the number of household members between 15 and 64 years, is not statistically significant. The average value of non-land assets is about 4.6 million Myanmar Kyat 
Table 3 Characteristics of sample rice plots

\begin{tabular}{|c|c|c|c|c|c|c|c|c|}
\hline & \multicolumn{2}{|l|}{ Total } & \multicolumn{2}{|c|}{ Plots with HYVs } & \multicolumn{2}{|c|}{ Plots with HVVs } & \multicolumn{2}{|c|}{ Plots with LVs } \\
\hline & Mean & SD & Mean & SD & Mean & SD & MEAN & SD \\
\hline Number of plots & 393 & & 33 & & 213 & & 147 & \\
\hline Plot size (acres) & 8.83 & $(6.20)$ & $5.52 * *$ & $(3.84)$ & $9.93 * * *$ & $(6.25)$ & 7.98 & $(6.18)$ \\
\hline Plot in a high location $(=1)$ & 0.34 & $(0.47)$ & $0.45^{* * *}$ & $(0.51)$ & $0.43 * * *$ & $(0.50)$ & 0.18 & $(0.38)$ \\
\hline Irrigation $(=1)$ & 0.28 & $(0.45)$ & 0.18 & $(0.39)$ & 0.27 & $(0.45)$ & 0.31 & $(0.46)$ \\
\hline Drainage $(=1)$ & 0.45 & $(0.50)$ & $0.30 *$ & $(0.47)$ & 0.47 & $(0.50)$ & 0.46 & $(0.50)$ \\
\hline Public dike $(=1)$ & 0.55 & $(0.50)$ & $0.21 * * *$ & $(0.42)$ & $0.68 * * *$ & $(0.47)$ & 0.46 & $(0.50)$ \\
\hline Private dike $(=1)$ & 0.17 & $(0.38)$ & 0.15 & $(0.36)$ & $0.13 * *$ & $(0.34)$ & 0.23 & $(0.42)$ \\
\hline Distance to the nearest river or coastal line (m) & 934 & $(736)$ & 693 & $(686)$ & 974 & $(702)$ & 932 & $(786)$ \\
\hline Distance to homestead (m) & 1202 & $(1105)$ & $1570 * *$ & $(1338)$ & 1212 & $(1134)$ & 1106 & $(0.990)$ \\
\hline Saltwater intrusion $(=1)$ & 0.23 & $(0.42)$ & $0.12 * *$ & $(0.33)$ & $0.18 * * *$ & $(0.39)$ & 0.31 & $(0.47)$ \\
\hline Yield (kg/acre) & 892 & $(347)$ & $1059 * * *$ & $(426)$ & 898 & $(329)$ & 847 & $(344)$ \\
\hline Rice income (MMK/acre) & 114,148 & $(134,151)$ & 86,733 & $(119,686)$ & $147,516^{* * *}$ & $(133,857)$ & 72,062 & $(124,890)$ \\
\hline Rice profit (MMK/acre) & 7439 & $(184,500)$ & $-24,132$ & $(185,730)$ & $53,063 * * *$ & $(177,026)$ & $-51,451$ & $(177,701)$ \\
\hline Amount of seed planted $(\mathrm{kg})$ & 19.7 & $(15.4)$ & 22.5 & $(17.6)$ & 18.8 & $(14.0)$ & 20.5 & $(16.8)$ \\
\hline Cost of chemical fertilizer (MMK) & 265,045 & $(291,601)$ & $405,818 * * *$ & $(385,476)$ & $290,432 * * *$ & $(291,583)$ & 196,657 & $(249,302)$ \\
\hline Cost of other agro-chemicals (MMK) & 6354 & $(34,689)$ & 7167 & $(13,749)$ & 7547 & $(41,984)$ & 4442 & $(24,979)$ \\
\hline Cost of harvest machinery (MMK) & 363,277 & $(363,987)$ & 366,182 & $(289,815)$ & 368,573 & $(352,408)$ & 354,950 & $(396,058)$ \\
\hline Cost of hired labor (MMK) & 414,129 & $(357,762)$ & 402,666 & $(298,424)$ & 414,672 & $(367,136)$ & 415,916 & $(358,303)$ \\
\hline Total days of family labor used & 41.3 & $(67.63)$ & 41.5 & $(61.67)$ & 44.1 & $(72.50)$ & 37.1 & $(61.53)$ \\
\hline Total days of exchange labor used & 104.2 & $(111.08)$ & 96.9 & $(113.10)$ & 98.8 & $(109.19)$ & 113.7 & $(113.44)$ \\
\hline
\end{tabular}

$* * *$ and $* *$ indicate significance at $1 \%$ and $5 \%$, respectively

We conducted significance testing of the differences in means between plots with HYVs and those with only LVs, and plots with HVVs and those with LVs

(MMK), which is approximately 3451 USD. ${ }^{8}$ Households that plant HYVs and HVVs experience significantly less saltwater intrusion into their farms than those that plant LVs only. Thus, the experience of saltwater intrusion may have affected the decision to adopt the rice seeds. Households that experienced saltwater intrusion may not have planted HYVs and HVVs to avoid the risk of being unable to recoup their investment. The scale of the degree of risk tolerance is from two to nine, with two indicating the most risk aversion and nine indicating the least (most risk tolerant). ${ }^{9}$ The average degree of risk tolerance was 2.13 , which indicates that most of the rice farmers in the survey areas are quite risk averse. Risk tolerance is the highest among adopters of HYVs and the lowest for those planting LVs only. This trend could indicate that the more risk-averse households preferred LVs, whereas the more risk-tolerant households preferred HYVs.

\footnotetext{
${ }^{8}$ We used the currency exchange rate as of January 27, 2021: 1 MMK $=0.00075$ USD.

9 The detailed description of the variable "risk tolerance" is provided in the "Appendix".
}

Table 3 compares rice plot characteristics, output, and input use between plots with HYVs, HVVs, and LVs in the wet season of 2016. Land size is significantly smaller for plots with HYVs, and significantly larger for those with HVVs than those with LVs. The heights of plots with HYVs and HVVs tend to be significantly higher than those with LVs. The low tolerance of HYVs and HVVs to flooding and saltwater intrusion compared with LVs may have influenced farmers' choice in planting HYVs and HVVs in plots on higher grounds - to minimize plot submergence and saltwater intrusion. The ratio of plots with public dikes is lower for plots with HYVs compared with other plots, though it is higher for those with HVVs among others. The survey revealed the quality of public dikes to be heterogeneous; these facilities might not have contributed to farmers' decisions to adopt HYVs. ${ }^{10}$ The ratio of plots with private dikes is the highest for plots with only LVs. The reason may be that these plots are in the especially low areas and farmers invest major effort to avoid plot submergence and saltwater

\footnotetext{
${ }^{10}$ In 2016, the local government started to construct new public dikes and/or carry out maintenance on public dikes. Thus, the situation in the survey areas may currently be better.
} 
Table 4 Adoption determinants of HYVs and HVVs: plot-level MNL estimates (marginal effect at means)

\begin{tabular}{|c|c|c|c|}
\hline & LVs & Adoption of HYVs & HVVs \\
\hline Plot size (acre) & $\begin{array}{l}-0.033 * * * \\
-0.009\end{array}$ & $\begin{array}{l}-0.000005 \\
(0.00002)\end{array}$ & $\begin{array}{l}0.033 * * * \\
(0.009)\end{array}$ \\
\hline Squared plot size (acre) & $\begin{array}{l}0.0006 * * \\
(0.0003)\end{array}$ & $\begin{array}{l}-0.000001 \\
(0.000001)\end{array}$ & $\begin{array}{l}-0.001 * * \\
(0.0003)\end{array}$ \\
\hline Plot in a high location $(=1)$ & $\begin{array}{l}-0.241 * * * \\
(0.047)\end{array}$ & $\begin{array}{l}0.000141 * * * \\
-0.00004\end{array}$ & $\begin{array}{l}0.240 * * * \\
-0.047\end{array}$ \\
\hline Irrigation $(=1)$ & $\begin{array}{l}-0.036 \\
(0.081)\end{array}$ & $\begin{array}{l}-0.0002 \\
(0.0001)\end{array}$ & $\begin{array}{l}0.037 \\
(0.081)\end{array}$ \\
\hline Drainage $(=1)$ & $\begin{array}{l}0.0006 \\
(0.119)\end{array}$ & $\begin{array}{l}0.0001 * \\
(0.0001)\end{array}$ & $\begin{array}{l}-0.001 \\
(0.119)\end{array}$ \\
\hline Public dike $(=1)$ & $\begin{array}{l}-0.074 \\
(0.094)\end{array}$ & $\begin{array}{l}-0.0004 \\
(0.0001)\end{array}$ & $\begin{array}{l}0.074 \\
(0.094)\end{array}$ \\
\hline Private dike $(=1)$ & $\begin{array}{l}0.035 \\
(0.105)\end{array}$ & $\begin{array}{l}-0.00001 \\
(0.00004)\end{array}$ & $\begin{array}{l}-0.035 \\
(0.105)\end{array}$ \\
\hline Distance to the nearest river or coastal line (m) & $\begin{array}{l}-0.00002 \\
(0.00004)\end{array}$ & $\begin{array}{l}-0.00000003 \\
-0.00000003\end{array}$ & $\begin{array}{l}0.00002 \\
-0.00004\end{array}$ \\
\hline Distance to the homestead (m) & $\begin{array}{l}0.00001 \\
(0.00003)\end{array}$ & $\begin{array}{l}0.0000001 * * * \\
-0.00000001\end{array}$ & $\begin{array}{l}-0.00001 \\
-0.00003\end{array}$ \\
\hline Woman-headed household $(=1)$ & $\begin{array}{l}-0.008 \\
(0.086)\end{array}$ & $\begin{array}{l}-0.00007 \\
(0.00006)\end{array}$ & $\begin{array}{l}0.008 \\
(0.086)\end{array}$ \\
\hline Age of the head (years) & $\begin{array}{l}0.003 \\
(0.004)\end{array}$ & $\begin{array}{l}-0.000001 \\
(0.000001)\end{array}$ & $\begin{array}{l}-0.002 \\
(0.004)\end{array}$ \\
\hline Schooling years of the household head & $\begin{array}{l}-0.007 \\
(0.0135)\end{array}$ & $\begin{array}{l}-0.000009 \\
(0.000008)\end{array}$ & $\begin{array}{l}0.007 \\
(0.014)\end{array}$ \\
\hline Number of working adults (aged 15-64 years) & $\begin{array}{l}-0.026^{*} \\
(0.0155)\end{array}$ & $\begin{array}{l}0.000009 \\
-0.00001\end{array}$ & $\begin{array}{l}0.025^{*} \\
-0.016\end{array}$ \\
\hline Value of non-land assets & $\begin{array}{l}0.00000002 * * \\
(0.00000001)\end{array}$ & $\begin{array}{l}0.00000000001 \\
(0.00000000001)\end{array}$ & $\begin{array}{l}-0.00000002 * * \\
(0.00000001)\end{array}$ \\
\hline Experience of saltwater intrusion in the past nine years & $\begin{array}{l}0.134 * * \\
(0.053)\end{array}$ & $\begin{array}{l}-0.00004 \\
(0.00006)\end{array}$ & $\begin{array}{l}-0.134^{* *} \\
(0.053)\end{array}$ \\
\hline Experience of having cyclone in the past nine years & $\begin{array}{l}0.03 \\
(0.050)\end{array}$ & $\begin{array}{l}-0.0001 * * * \\
(0.00004)\end{array}$ & $\begin{array}{l}-0.0298 \\
(0.050)\end{array}$ \\
\hline Experience of drought in the past nine years & $\begin{array}{l}0.04 \\
(0.027)\end{array}$ & $\begin{array}{l}0.00004 \\
-0.00002\end{array}$ & $\begin{array}{l}-0.0403 \\
-0.027\end{array}$ \\
\hline Experience of other climate shocks in the past nine years & $\begin{array}{l}0.005 \\
(0.015)\end{array}$ & $\begin{array}{l}0.000004 \\
-0.00002\end{array}$ & $\begin{array}{l}-0.005 \\
-0.015\end{array}$ \\
\hline Degree of risk tolerance (from 2 to 9 ) & $\begin{array}{l}-0.012 \\
(0.015)\end{array}$ & $\begin{array}{l}0.00003 * * * \\
(0.00001)\end{array}$ & $\begin{array}{l}0.012 \\
(0.015)\end{array}$ \\
\hline Observations & 393 & 393 & 393 \\
\hline
\end{tabular}

Standards errors, which clustered at the village level are in parentheses

All estimates are weighted by attrition weights

Village tract dummies are included in all estimations

$* * * p<0.01 ; * * p<0.05 ; * p<0.1$

intrusion. Additionally, the plots with HYVs tended to be nearer the river or coastal line and further from the homestead compared with plots planted with other varieties (Table 4).
As expected, rice yield is the highest for plots with HYVs (1059 kg/acre) and the lowest for plots with LVs $(847 \mathrm{~kg} /$ acre) among the household groups. Average rice income is the highest for plots with HVVs among other groupstwice as high as those with LVs. The average profits are 
low, especially for plots with HYVs and LVs, because the shadow price of family labor could be overvalued. As Takahashi et al. (2019) noted, the accurate imputation of family labor costs is quite difficult, and negative profits are common owing to the overvaluation of family labor costs. They suggest that estimated profits could be used as ordinal numbers, instead of cardinal. The profits are the highest for plots with HVVs and lowest for those with LVs. Thus, economic returns are the highest for groups that adopted HVVs. Regarding input use, the use of chemical fertilizer on the plots with HYVs is highest (53\% more than the average) and that on LVs is the lowest (26\% less than the average).

The simple tabulations presented in the descriptive analysis provide preliminary insights on adoption and output determinants. We conduct multivariate econometrics analyses to draw inferences on the adoption determinants of HYVs and HVVs and their effect on rice yield, income, and profit.

\section{Estimation results}

\section{Determinants of adoption of HYVs and HVVs}

Table 4 presents the marginal effect at the means of MNL estimation. The base category is the adoption of LVs. The model fits the data well; the likelihood-tests, in which the coefficients of regressors were all jointly equal to zero, are rejected because the likelihood ratio chi-squared (56) equals 199.31 .

Plot size and squared plot size are statistically significant for the adoption of HVVs in the model, leading to a quadratic relation between land size and the adoption of HVVs. The adoption rate would increase as land size increased up to a certain threshold, and then it would decrease. Although distance to the homestead, rice plots in high locations, and drainage of the plots, positively and significantly relate to the adoption of HYVs, the magnitude of the marginal effect at the means is quite small. While LVs are less likely to be planted in the rice plots in high locations, HYVs and HVVs, which are not salt and flood tolerant, are more likely to be planted in high locations. The planting of LVs on the plots in the lower areas, where flooding and saltwater intrusion could occur, may be part of the coping strategies of farmers. As mentioned, LVs have flood- and salt-tolerant traits. If the household has one more working adult, the probability of adopting HVVs is expected to increase by 0.025 , and the probability of adopting LVs at its mean is expected to decrease by 0.026 . Although the value of non-land assets was significantly and positively associated with LV adoption, and negatively associated with HVV adoption, the magnitude of the coefficient was small.
The regression results confirmed that past exposure to climate shocks would discourage farmers from adopting HVVs. One more saltwater intrusion in their plots in the last nine years was likely to reduce the probability of adopting HVVs by 0.134 and to increase the of adopting LVs by 0134. Having one more experience of a cyclone in the last nine years also decreased the probability of the adoption of HYVs but its magnitude was quite small. These estimation results support our hypothesis that past exposure to weather shocks would negatively affect rice farmers' adoption decisions, especially regarding HVVs. Previous research has also indicated that weather shocks negatively affect the adoption of agricultural technologies (Alem et al. 2010; Arslan et al. 2017).

To capture the risk preference of rice farmers, we included the degree of risk tolerance in the model. A low value for the degree of risk tolerance indicated risk aversion and a high-value indicated risk-seeking. The estimation results demonstrated that more risk-loving farmers were more likely to adopt HYVs, though the magnitude of the effect was negligible.

\section{Association between the adoption of HYVs and HVVs, rice yield, and income}

Table 5 shows the effects of adoption of HYVs and HVVs on land productivity, measured by the log of rice yield per acre (in Column 1), rice income per acre (in Column 2), and rice profit per acre (in Column 3) on a rice plot in the wet season in 2016. Our variables of interest are dummy variables of the adoption of HYVs and HVVs, and the base category is that of LVs.

Our results indicate that the adoption of HYVs is not likely to be related to high yield and monetary returns. HYVs are not flood or salt tolerant and are supposed to be planted in the uplands. Hence, the current HYVs would be unable to live up to their potential in the low-lying, coastal areas of the Ayeyarwady River delta.

Although the land productivity of plots adopting HVVs is not statistically different from plots planted with LVs, the adoption of HVVs is associated with statistically higher income per acre by 43,154 MMK (equivalent to 26.2 USD) and higher profit per acre by 38,633 MMK (23.47 USD) than plots with LVs. The increases could be because of the high sales prices of HVVs. HVVs are likely to be the most profitable varieties in the survey areas.

Table 6 shows the results of two robustness tests to check for omitted variable bias. Column (5) shows an estimated $\delta$ such that delivers our estimated coefficients of treatment to zero. The value of $\delta$ of HVVs dummy in the second panel (estimation for rice income) is 2.008. This indicates that unobservable variables need to have 2.008 times more impact than control variables to drive the treatment effect 
Table 5 Association of HYVs and HVVs and rice yield, income, and profit: plot level OLS estimates

\begin{tabular}{|c|c|c|c|}
\hline Variables & $\begin{array}{l}\text { Log of rice } \\
\text { yield (kg/acre) } \\
\text { (1) }\end{array}$ & $\begin{array}{l}\text { Rice income } \\
\text { (MMK/acre) (2) }\end{array}$ & $\begin{array}{l}\text { Rice profit } \\
\text { (MMK/acre) } \\
\text { (3) }\end{array}$ \\
\hline HYVs $(=1)$ & $\begin{array}{l}0.039 \\
(0.102)\end{array}$ & $\begin{array}{l}-6065 \\
(10,974)\end{array}$ & $\begin{array}{l}-764 \\
(6980)\end{array}$ \\
\hline HVVs $(=1)$ & $\begin{array}{l}-0.012 \\
(0.042)\end{array}$ & $\begin{array}{l}43,154 * * * \\
(11,157)\end{array}$ & $\begin{array}{l}38,633 * * \\
(12,173)\end{array}$ \\
\hline Log of plot size (acre) & $\begin{array}{l}-0.007 \\
(0.018)\end{array}$ & $\begin{array}{l}4023 \\
(7186)\end{array}$ & $\begin{array}{l}-3942 \\
(4357)\end{array}$ \\
\hline Plot in a high location $(=1)$ & $\begin{array}{l}0.075 \\
(0.061)\end{array}$ & $\begin{array}{l}13,217 \\
(10,277)\end{array}$ & $\begin{array}{l}10,569 \\
(8824)\end{array}$ \\
\hline Irrigation $(=1)$ & $\begin{array}{l}0.024 \\
(0.077)\end{array}$ & $\begin{array}{l}10,986 \\
(18,280)\end{array}$ & $\begin{array}{l}-7414 \\
(19,265)\end{array}$ \\
\hline Drainage $(=1)$ & $\begin{array}{l}-0.038 \\
(0.064)\end{array}$ & $\begin{array}{l}-13,100 \\
(14,635)\end{array}$ & $\begin{array}{l}-27,752^{*} \\
(13,100)\end{array}$ \\
\hline Public dike (=1) & $\begin{array}{l}0.043 \\
(0.119)\end{array}$ & $\begin{array}{l}7409 \\
(12,734)\end{array}$ & $\begin{array}{l}16,575 \\
(15,062)\end{array}$ \\
\hline Private dike $(=1)$ & $\begin{array}{l}-0.042 \\
(0.099)\end{array}$ & $\begin{array}{l}22,680 * * \\
(9285)\end{array}$ & $\begin{array}{l}19,364 * * \\
(7901)\end{array}$ \\
\hline Distance to the nearest river $(\mathrm{m})$ & $\begin{array}{l}0.000 \\
(0.000)\end{array}$ & $\begin{array}{l}11.471 \\
(7.777)\end{array}$ & $\begin{array}{l}6.909 \\
(8.424)\end{array}$ \\
\hline Distance to the homestead (m) & $\begin{array}{l}-0.00005^{* *} \\
0\end{array}$ & $\begin{array}{l}-6.161 \\
-5.439\end{array}$ & $\begin{array}{l}-2.187 \\
-5.917\end{array}$ \\
\hline Saline water intrusion in $2016(=1)$ & $\begin{array}{l}-0.211^{* *} \\
(0.076)\end{array}$ & $\begin{array}{l}-20,505 \\
(13,974)\end{array}$ & $\begin{array}{l}6317 \\
(14,157)\end{array}$ \\
\hline Woman-headed household $(=1)$ & $\begin{array}{l}0.043 \\
(0.074)\end{array}$ & $\begin{array}{l}-27,780 \\
(19,778)\end{array}$ & $\begin{array}{l}-32,965^{* *} \\
(14,287)\end{array}$ \\
\hline Age of the head & $\begin{array}{l}-0.004^{*} \\
(0.002)\end{array}$ & $\begin{array}{l}-124 \\
(600)\end{array}$ & $\begin{array}{l}-504 \\
(531)\end{array}$ \\
\hline Schooling years of the head & $\begin{array}{l}-0.013 \\
(0.009)\end{array}$ & $\begin{array}{l}-2438 \\
(3404)\end{array}$ & $\begin{array}{l}-3985 \\
(2486)\end{array}$ \\
\hline Number of working adults (age 15-64) & $\begin{array}{l}-0.004 \\
(0.018)\end{array}$ & $\begin{array}{l}-6260 \\
(6103)\end{array}$ & $\begin{array}{l}-5367 \\
(7575)\end{array}$ \\
\hline Log of value of non-land assets & $\begin{array}{l}0.087 * * \\
(0.034)\end{array}$ & $\begin{array}{l}23,052 * * \\
(7908)\end{array}$ & $\begin{array}{l}28,197 * * * \\
(6355)\end{array}$ \\
\hline Experience of saltwater intrusion in the past nine years & $\begin{array}{l}0.046 \\
(0.062)\end{array}$ & $\begin{array}{l}2661 \\
(17,930)\end{array}$ & $\begin{array}{l}-14,969 \\
(16,190)\end{array}$ \\
\hline Experience of having cyclone in the past nine years & $\begin{array}{l}0.097 * \\
(0.048)\end{array}$ & $\begin{array}{l}21,315 \\
(16,551)\end{array}$ & $\begin{array}{l}-5269 \\
(13,616)\end{array}$ \\
\hline Experience of drought in the past nine years & $\begin{array}{l}-0.014^{*} \\
(0.007)\end{array}$ & $\begin{array}{l}-1076 \\
(2596)\end{array}$ & $\begin{array}{l}-5400^{* *} \\
(2103)\end{array}$ \\
\hline Experience of other climate shocks in the past nine years & $\begin{array}{l}-0.008 \\
(0.009)\end{array}$ & $\begin{array}{l}-5778^{* *} \\
(2119)\end{array}$ & $\begin{array}{l}-5644 * * * \\
(1598)\end{array}$ \\
\hline Degree of risk tolerance (from 2 to 9 ) & $\begin{array}{l}0.012 \\
(0.011)\end{array}$ & $\begin{array}{l}3656 \\
(3309)\end{array}$ & $\begin{array}{l}1433 \\
(3315)\end{array}$ \\
\hline Constant & $\begin{array}{l}2.674 * * * \\
(0.453)\end{array}$ & $\begin{array}{l}-217,464 \\
(132,479)\end{array}$ & $\begin{array}{l}-255,621 * * \\
(105,703)\end{array}$ \\
\hline Observations & 393 & 388 & 388 \\
\hline$R$-squared & 0.227 & 0.271 & 0.289 \\
\hline
\end{tabular}

Standards errors, which clustered at the village level are in parentheses

All estimates are weighted by attrition weights

Village tract dummies are included in all estimations

$* * * p<0.01 ; * * p<0.05 ; * p<0.1$ 
Table 6 Estimation outcome of rice variety choices and Oster's robustness tests

\begin{tabular}{llllcc}
\hline Outcome variables (1) & Treatment variables (2) & $\begin{array}{l}\text { Estimated coef- } \\
\text { ficient (3) }\end{array}$ & S.E. (4) & $\begin{array}{l}\delta \text { for } \beta=0 \text { given } \\
R_{\max }(5)\end{array}$ & $\begin{array}{l}\text { Coefficient bounds (6) } \\
\text { Log of rice yield (kg/acre) }\end{array}$ \\
& HYVs (=1) & 0.039 & 0.102 & 0.627 & $(-0.027,0.039)$ \\
& HVVs (=1) & -0.012 & 0.042 & -0.767 & $(-0.032,-0.012)$ \\
Rice income (MMK/acre) & HYVs (=1) & -6065 & 10,974 & 0.455 & $(-6065,8460)$ \\
& HVVs (=1) & $43,154 * * *$ & 11,157 & 2.008 & $(29,205,43,158)$ \\
Rice profit (MMK/acre) & HYVs (=1) & -764 & 6980 & 0.064 & $(-764,12,815)$ \\
& HVVs (=1) & $38,633^{* *}$ & 12,173 & 2.349 & $(29,128,38,633)$ \\
\hline
\end{tabular}

(3) $* * * p<0.01 ; * * p<0.05 ; * p<0.1$

(5) $\delta$ is calculated as it produces $\beta=0$ given $R_{\max }$ that is calculated in each panel

(6) Coefficient bounds are below $\tilde{\beta}$ and above $\beta^{*}$ calculated based on $R_{\max }$ given $\tilde{\delta}=1$

to zero. According to Oster (2019), since this value of $\delta$ is greater than 1 , the estimates would be robust to the omitted variables. Similarly, the value of $\delta$ of HVVs dummy in the third panel (estimation for rice profit) is 2.349 , which also indicates the effect would be robust.

Column (6) of Table 6 shows the coefficient bounds, which are calculated below $\tilde{\beta}$ and above $\beta^{*}$ based on $R_{\max }$, given that $\delta=1$ Oster (2019) discusses that if these coefficient bounds do not contain zero, the estimate is robust to unobserved heterogeneity. For HVVs dummy in the second and third panels, both coefficient intervals do not contain zero, which also suggests that our estimates are robust.

Table 5 shows that saltwater intrusion into the plots in the 2016 cropping season is negatively associated with rice yield. The number of droughts experienced in the last nine years is negatively associated with rice yield and profit. Additionally, having experienced other climate shocks in the past nine years also has negative consequences for rice income and profit. This indicates that climate shocks are likely to relate to low rice yield, income, and profit.

Having private dikes in the plots has positive associations with rice income and profit, suggesting farmers' efforts to prevent water intrusion might secure their rice income and profit. However, the drainage is negatively associated with rice profit, which implies that water drainage might not be effective in the survey areas. The value of non-land assets has a significantly positive association with rice yield, income, and profit. An implication is that the wealthier farmers could conduct more profitable rice farming. ${ }^{11}$

\footnotetext{
11 Utilizing the fact that there was a subset of households who planted HYVs (or HVVs) on one plot and LVs on a different plot, we estimated within-household plot-level fixed-effect models of (4) as a robustness check. Then we found that the qualitative results are like the results in Table 5.
}

\section{Conclusion and policy implications}

Among agricultural products, rice is the most highly cultivated product in Myanmar. Increasing rice productivity and profitability is one of the most important means to improving rural households' income and welfare. To raise crop income, farmers can increase their crop productivity and/or grow high-value crops. However, empirical research on the various choices of crop varieties, such as HYVs, HVVs, and LVs, remains scarce. Therefore, we focused on the adoption of HYVs to increase crop productivity and HVVs (Paw San series rice) to obtain high revenue. Our study attempted to quantify the adoption determinants of HYVs and HVVs through the MNL model. We then assessed their association on rice yield, income, and profits, and conducted robustness tests to omitted variable bias by estimating Oster's bias-adjusted treatment effect.

Our results show that farmers tend to plant HYVs and HVVs on plots in upland areas. Past exposure to climate shocks such as saltwater intrusion may negate farmers' incentive to adopt HVVs. Thus, the rice variety choices of local farmers are rational and based on their knowledge and experience- the HYVs and HVVs adopted in the survey areas are not salt and flood tolerant, whereas LVs are.

Contrary to the literature (e.g., Bezu et al. 2014; Villano et al. 2015), our estimation results suggest that the adoption of HYVs is not associated with high yield, income, or profit. The reason may be because of the overly harsh environmental conditions in the coastal areas of the Ayeyarwady River delta for HYVs, which are neither flood nor salt tolerant. In contrast, the adoption of HVVs is associated with high rice income and profit per acre. Thus, the adoption of HVVs could be an effective way to increase the income and profits of rice farmers in the low-lying, coastal areas in Myanmar. 
Table 7 Risk preference experiment

\begin{tabular}{|c|c|c|c|c|c|}
\hline \multirow{2}{*}{$\begin{array}{l}\text { Game num- } \\
\text { ber }\end{array}$} & \multicolumn{2}{|l|}{ If you play the game, } & \multirow{2}{*}{$\begin{array}{l}\text { If you do not play, you will receive the } \\
\text { following fixed amount (MMK) }\end{array}$} & \multicolumn{2}{|c|}{ Will you play the game? } \\
\hline & $\begin{array}{l}\text { You win if dice }=1,2, \\
3(\mathrm{MMK})\end{array}$ & $\begin{array}{l}\text { you lose if dice }=4,5, \\
6(\mathrm{MMK})\end{array}$ & & $\begin{array}{l}\text { Yes, I will play } \\
\text { the game }\end{array}$ & $\begin{array}{l}\text { No, I will receive } \\
\text { the fixed amount }\end{array}$ \\
\hline 1 & 10,000 & 2000 & 2000 & & \\
\hline 2 & 10,000 & 2000 & 3000 & & \\
\hline 3 & 10,000 & 2000 & 4000 & & \\
\hline 4 & 10,000 & 2000 & 5000 & & \\
\hline 5 & 10,000 & 2000 & 6000 & & \\
\hline 6 & 10,000 & 2000 & 7000 & & \\
\hline 7 & 10,000 & 2000 & 8000 & & \\
\hline 8 & 10,000 & 2000 & 9000 & & \\
\hline 9 & 10,000 & 2000 & 10,000 & & \\
\hline
\end{tabular}

Although the adoption of HVVs seems profitable, farmers cannot plant them on all their plots because HVVs are also neither submergence nor salt tolerant. For farmers in the coastal areas or river areas without embankments, the only viable choices are the LVs, which are resistant to these conditions. Thus, improving productivity and profitability of the paddy farms in the coastal areas in Myanmar would require the development of submergence- and salt-tolerant, highyielding and/or high-value rice varieties and diffuse them through extension. Another way is the development of good embankments, especially public dikes, and good drainage systems in the coastal areas to prevent saltwater intrusion. However, such infrastructure building would require careful analysis of the cost versus the benefits. The diffusion of weather index insurance is another way to protect farmers from catastrophic weather shocks and can be expected to promote the adoption of modern agricultural technologies by farmers in areas vulnerable to weather shocks (Cole et al. 2017; Freudenreich and Mußhoff 2017). More research is necessary to formulate effective and inclusive approaches to improving the productivity and profitability of rice farming in the low-lying coastal areas of Myanmar.

\section{Appendix}

To elucidate farmers' risk preferences, we conducted one experimental exercise with the respondents. The game described below was hypothetical, and no actual payments were made to the respondents. The respondents were adult household members, often household heads who made the decisions regarding farming technology adoption. The

\footnotetext{
12 We refer to the experimental exercises in Tanaka et al. (2010) and Takahashi and Barrett (2013).
}

experimental exercise is shown in Table 7 in "Appendix". ${ }^{12}$ We asked the respondents the following.

Please imagine you are given a chance to play a lottery game as shown in Table 7 in "Appendix". In the game, you roll a dice, and if it shows 1,2 , or 3, you win $10,000 \mathrm{MMK}$; if it shows 4, 5, or 6, you lose and get only 2000 MMK. If you do no not play the game, you will receive the fixed amount specified in the cells in Table 7 in "Appendix". Will you play the game or opt to receive the fixed amount of money?

In Game number 1, all the respondents must play the game since the lower payoff of the game was equal to the fixed amount, which indicates that respondents always have the chance to earn more by playing Game number 1, than choosing the fixed amount. Thus, the real choice experiment starts from Game number 2 and not from Game number 1. Game 1 was included to check whether the respondents understood the game. We ran a series of games, from 1 to 9 , and determined when respondents switched from "yes" to "no." We ensured that the respondents could not switch back from "no" to "yes." Since the expected value of the game was always $6000 \mathrm{MMK}$, the risk-neutral respondent would switch from "yes" to "no" by game number 5 or 6 . The risk-averse respondents would switch from "yes" to "no" before game number 5. The risk-tolerant respondents would switch from "yes" to "no" after game number 7 . We used the switching point, which is from games 2 to 9 , as the degree of risk tolerance. A higher number indicated higher risk tolerance.

The average number of switching points (degree of risk tolerance) was 2.13 . Indeed, most of the respondents switched from "yes" to "no" by game number 2, strongly suggesting that most of the respondents were risk averse.

Acknowledgements This study was conducted with the benefit of the budget of the Japan International Research Center for Agricultural 
Sciences (JIRCAS) project on "Climate Change Measures in Agricultural Systems: Development of agricultural technologies for reducing greenhouse gas emissions and climate-related risks in developing countries." This manuscript is the part of the Special Issue titled "Weather Index Insurance for Rice Farmers in Myanmar" in volume 19, issue 2, which was published in April 2021. We extend our sincere appreciation to Khin Lay Swe, Kyaw Ngwe, Myo Kywe, Soe Soe Thein, and Swe Swe Mar of the Yezin Agricultural University. They were supporting farm surveys in Labutta Township. We are also grateful to helpful comments and suggestions made by anonymous referees.

Open Access This article is licensed under a Creative Commons Attribution 4.0 International License, which permits use, sharing, adaptation, distribution and reproduction in any medium or format, as long as you give appropriate credit to the original author(s) and the source, provide a link to the Creative Commons licence, and indicate if changes were made. The images or other third party material in this article are included in the article's Creative Commons licence, unless indicated otherwise in a credit line to the material. If material is not included in the article's Creative Commons licence and your intended use is not permitted by statutory regulation or exceeds the permitted use, you will need to obtain permission directly from the copyright holder. To view a copy of this licence, visit http://creativecommons.org/licenses/by/4.0/.

\section{References}

Alem Y, Bezabih M, Kassie M, Zikhali P (2010) Does fertilizer use respond to rainfall variability? Panel data evidence from Ethiopia. Agric Econ 41:165-175. https://doi.org/10.1111/j.1574-0862. 2009.00436.x

Ali A, Abdulai A (2010) The adoption of genetically modified cotton and poverty reduction in Pakistan. J Agric Econ 61:175-192. https://doi.org/10.1111/j.1477-9552.2009.00227.x

Altonji JG, Elder TE, Taber CR (2005) Selection on observed and unobserved variables: assessing the effectiveness of catholic schools. J Polit Econ 113:151-184. https://doi.org/10.1086/ 426036

Amare M, Mariara J, Oostendorp R, Pradhan M (2019) The impact of smallholder farmers' participation in avocado export markets on the labor market, farm yields, sales prices, and incomes in Kenya. Land Use Policy 88:104168. https://doi.org/10.1016/j.landusepol. 2019.104168

Arslan A, Belotti F, Lipper L (2017) Smallholder productivity and weather shocks: adoption and impact of widely promoted agricultural practices in Tanzania. Food Policy 69:68-81. https://doi. org/10.1016/j.foodpol.2017.03.005

Asian Development Bank (2021) Myanmar and ADB, poverty data, Myanmar. https://www.adb.org/countries/myanmar/poverty\#: : text=Poverty\%20Data\%3A\%20Myanmar,day\%20in\%202019\% 20is\%202.7\%25. Accessed 29 Jan 2021

Banerjee AV, Banerjee A, Duflo E (2011) Poor economics: a radical rethinking of the way to fight global poverty. Public Affairs

Becerril J, Abdulai A (2010) The impact of improved maize varieties on poverty in mexico: a propensity score-matching approach. World Dev 38:1024-1035. https://doi.org/10.1016/j.worlddev. 2009.11.017

Bezu S, Kassie GT, Shiferaw B, Ricker-Gilbert J (2014) Impact of improved maize adoption on welfare of farm households in Malawi: a panel data analysis. World Dev 59:120-131. https:// doi.org/10.1016/j.worlddev.2014.01.023

Briones RM (2015) Small farmers in high-value chains: binding or relaxing constraints to inclusive growth? World Dev 72:43-52. https://doi.org/10.1016/j.worlddev.2015.01.005
Cameron AC, Trivedi PK (2010) Microeconometrics using stata. Stata Press, College Station

Carletto C, Savastano S, Zezza A (2013) Fact or artifact: the impact of measurement errors on the farm size-productivity relationship. J Dev Econ 103:254-261. https://doi.org/10.1016/j.jdeveco.2013. 03.004

Cavatassi R, Lipper L, Narloch U (2011) Modern variety adoption and risk management in drought prone areas: insights from the sorghum farmers of eastern Ethiopia. Agric Econ 42:279-292. https://doi.org/10.1111/j.1574-0862.2010.00514.x

Cole S, Giné X, Vickery J (2017) How does risk management influence production decisions? Evidence from a field experiment. Rev Financ Stud 30:1935-1970. https://doi.org/10.1093/rfs/hhw080

Crost B, Shankar B, Bennett R, Morse S (2007) Bias from farmer self-selection in genetically modified crop productivity estimates: evidence from Indian data. J Agric Econ 58:24-36. https://doi.org/ 10.1111/j.1477-9552.2007.00076.x

Deaton A, Drèze J (2009) Food and nutrition in India: facts and interpretations. Econ Polit Wkly 24:66

FAOSTAT (2021) http://www.fao.org/faostat/en/\#data. Accessed 29 Jan 2021

Fitzgerald J, Gottschalk P, Moffitt R (1998) An analysis of sample attrition in panel data: the Michigan panel study of income dynamics. J Hum Resour 33:251-299. https://doi.org/10.2307/146433

Food and Agriculture Organization (2021) GIEWS — global information and early warning system. http://www.fao.org/giews/count rybrief/country.jsp?code=MMR\&lang=en. Accessed 29 Jan 2021

Freudenreich H, Mußhoff O (2017) Insurance for technology adoption: an experimental evaluation of schemes and subsidies with maize farmers in Mexico. J Agric Econ 69:96-120. https://doi.org/10. $1111 / 1477-9552.12226$

Holden ST, Quiggin J (2017) Climate risk and state-contingent technology adoption: shocks, drought tolerance and preferences. Eur Rev Agric Econ 44:285-308. https://doi.org/10.1093/erae/jbw016

International Rice Research Institute (2020) Myanmar and IRRI. http:// books.irri.org/Myanmar_IRRI_brochure.pdf. Accessed 29 Jan 2021

Jensen RT, Miller NH (2008) Giffen behavior and subsistence consumption. Am Econ Rev 98:1553-1577. https://doi.org/10.1257/ aer.98.4.1553

Kassie M, Shiferaw B, Muricho G (2011) Agricultural technology, crop income, and poverty alleviation in Uganda. World Dev 39:17841795. https://doi.org/10.1016/j.worlddev.2011.04.023

Khan MF, Nakano Y, Kurosaki T (2019) Impact of contract farming on land productivity and income of maize and potato growers in Pakistan. Food Policy 85:28-39. https://doi.org/10.1016/j.foodp ol.2019.04.004

Khonje M, Manda J, Alene AD, Kassie M (2015) Analysis of adoption and impacts of improved maize varieties in Eastern Zambia. World Dev 66:695-706. https://doi.org/10.1016/j.worlddev.2014. 09.008

Manda J, Alene AD, Tufa AH et al (2019) The poverty impacts of improved cowpea varieties in Nigeria: a counterfactual analysis. World Dev 122:261-271. https://doi.org/10.1016/j.worlddev.2019. 05.027

Mathenge MK, Smale M, Olwande J (2014) The impacts of hybrid maize seed on the welfare of farming households in Kenya. Food Policy 44:262-271. https://doi.org/10.1016/j.foodpol.2013.09.013

Ministry of Agriculture and Irrigation (2015) Myanmar rice sector development strategy. http://books.irri.org/MRSDS_content.pdf. Accessed 29 Jan 2021

Ministry of Agriculture, Livestock and Irrigation (2019) Myanmar agriculture sector in brief. Nay Pyi Taw, Ministry of Agriculture, Livestock and Irrigation, Myanmar

Minten B, Murshid KAS, Reardon T (2013) Food quality changes and implications: evidence from the rice value chain of Bangladesh. 
World Dev 42:100-113. https://doi.org/10.1016/j.worlddev.2012. 06.015

Miyata S, Minot N, Hu D (2009) Impact of contract farming on income: linking small farmers, packers, and supermarkets in China. World Dev 37:1781-1790. https://doi.org/10.1016/j.worlddev.2008.08. 025

Myint PL, Napasintuwong O (2016) Economic analysis of paw san rice adoption in Myanmar. Asian J Agric Res 10:175-184. https://doi. org/10.3923/ajar.2016.175.184

Narayanan S (2014) Profits from participation in high value agriculture: evidence of heterogeneous benefits in contract farming schemes in Southern India. Food Policy 44:142-157. https://doi.org/10. 1016/j.foodpol.2013.10.010

Oster E (2019) Unobservable selection and coefficient stability: theory and evidence. J Bus Econ Stat 37:187-204. https://doi.org/10. 1080/07350015.2016.1227711

Rao EJO, Qaim M (2011) Supermarkets, farm household income, and poverty: insights from Kenya. World Dev 39:784-796. https://doi. org/10.1016/j.worlddev.2010.09.005

Smale M, Mason N (2014) Hybrid seed and the economic well-being of smallholder maize farmers in Zambia. J Dev Stud 50:680-695. https://doi.org/10.1080/00220388.2014.887690

Swiss Reinsurance Company Ltd. (2009) Natural catastrophes and man-made disasters in 2008. https://www.preventionweb.net/files/ 8841_Sigma22009e.pdf. Accessed 29 Jan 2021

Takahashi K, Barrett CB (2013) The system of rice intensification and its impacts on household income and child schooling: evidence from rural Indonesia. Am J Agr Econ 96:269-289. https://doi.org/ 10.1093/ajae/aat086

Takahashi K, Muraoka R, Otsuka K (2019) Technology adoption, impact, and extension in developing countries' agriculture: a review of the recent literature. Agric Econ 51:31-45. https://doi. org/10.1111/agec.12539
Tanaka T, Camerer CF, Nguyen Q (2010) Risk and time preferences: linking experimental and household survey data from Vietnam. Am Econ Rev 100:557-571. https://doi.org/10.1257/aer.100.1.557

Thant AA, Teutscherova N, Vazquez E et al (2020) On-farm rice diversity and farmers' preferences for varietal attributes in Ayeyarwady Delta, Myanmar. J Crop Improv 34:549-570. https://doi.org/10. $1080 / 15427528.2020 .1746457$

United Nations (2021) The 17 goals. https://sdgs.un.org/goals. Accessed 29 Jan 2021

United Nations Office for Project Services (2021) A new future for rural Myanmar. https://www.unops.org/news-and-stories/stori es/a-new-future-for-rural-myanmar. Accessed 29 Jan 2021

Verkaart S, Munyua BG, Mausch K, Michler JD (2017) Welfare impacts of improved chickpea adoption: A pathway for rural development in Ethiopia? Food Policy 66:50-61. https://doi.org/ 10.1016/j.foodpol.2016.11.007

Villano R, Bravo-Ureta B, Solís D, Fleming E (2015) Modern rice technologies and productivity in the Philippines: disentangling technology from managerial gaps. J Agric Econ 66:129-154. https://doi.org/10.1111/1477-9552.12081

Win UK (1991) A century of rice improvement in Burma. IRRI, Los Baños

Wooldridge JM (2010) Econometric analysis of cross section and panel data. MIT Press, London

World Bank (2019) Poverty Report-Myanmar Living Conditions Survey 2017. https://www.worldbank.org/en/country/myanmar/publi cation/poverty-report-myanmar-living-conditions-survey-2017. Accessed 29 Jan 2021

Zeng D, Alwang J, Norton GW et al (2015) Ex post impacts of improved maize varieties on poverty in rural Ethiopia: D. Zeng et al. Agric Econ 46:515-526. https://doi.org/10.1111/agec.12178 